\title{
Diesel Particulate Filter Modeling For Compression Ignition Engine
}

\author{
Khasim Sharif. SK ${ }^{1}$, D.Jagadish ${ }^{2,}$ K. Phaneendra Kumar ${ }^{3}$, K. Rakesh ${ }^{4}$ \\ ${ }^{I}$ (Assistant professor, Mechanical Department, CMRTC/ JNTUH, India) \\ ${ }^{2}$ (professor, Mechanical Department, VFSTR, India) \\ ${ }^{3}$ (professor\& principal, Mechanical Department, VLIT, India) \\ ${ }^{4}$ (B.Tech Student, Mechanical Department, CMRTC/ JNTUH, India)
}

\begin{abstract}
Diesel particulate filters capture particle emissions through a combination of filtration mechanisms, such as diffusion deposition, inertial deposition, or flow-line interception. Collected particulates are removed from the filter, continuously or periodically, through thermal regeneration. Diesel filters are highly effective in controlling solid particulate emissions-including solid particle numbers-but may be ineffective in controlling liquid fractions of PM emission. Filters were first commercialized as retrofit devices, followed by a wide scale adoption on new light-duty and heavy-duty diesel engines in both highway and non road applications.
\end{abstract}

Keywords: CPSI, DPF, HSU, MECA, PM

\section{Introduction}

Diesel particulate filters were introduced in 1985 on Mercedes cars sold in California. Particulate filters have been in use on non-road machines since 1980 and in automobiles since 1985 . Historically medium and heavy duty diesel engine emissions were not regulated until 1987 when the first California heavy truck rule was introduced capping particulate emissions at $0.60 \mathrm{~g} / \mathrm{bhp}$ hour [1]. The resulting exhaust is clean - no odor or diesel smell. This cleaner exhaust won't blacken your trailer, and won't even blacken inside of exhaust stack [2]. Since then, progressively tighter standards have been introduced for light- and heavy-duty road going diesel-powered vehicles and for off-road diesel engines. Similar regulations have also been adopted by the European Union and some individual European countries, most Asian countries, and the rest of north and South America [3].

This chapter explores the undesirable emissions generated in the combustion process of automobile and other IC engines. These emissions pollute the environment and contribute to global warming, acid rain, smog, odors, and respiratory and other health problems. The major causes of these emissions are non-stoichiometric combustion, dissociation of nitrogen, and impurities in the fuel and air. The emissions of concern are hydrocarbons (He), carbon monoxide (CO), oxides of nitrogen (NOx), sulfur, and solid carbon particulates. Ideally, engines and fuels could be developed such that very few harmful emissions are generated, and these could be exhausted to the surroundings without a major impact on the environment. With present technology this is not possible, and after treatment of the exhaust gases to reduce emissions is very important. This consists mainly of the use of thermal or catalytic converters and particulate traps [4].

\section{Air Pollution}

Until the middle of the 20th century the number of IC engines in the world was small enough that the pollution they emitted was tolerable, and the environment, with the help of sunlight, stayed relatively clean. As world population grew, power plants, factories, and an ever-increasing number of automobiles began to pollute the air to the extent that it was no longer acceptable. During the 1940s, air pollution as a problem was first recognized in the Los Angeles basin in California. Two causes of this were the large population density and the natural weather conditions of the area. The large population created many factories and power plants, as well as one of the largest automobile densities in the world. Smoke and other pollutants from the many factories and automobiles combined with fog that was common in this ocean area, and smog resulted. During the 1950s, the smog problem increased along with the increase in population density and automobile density. 


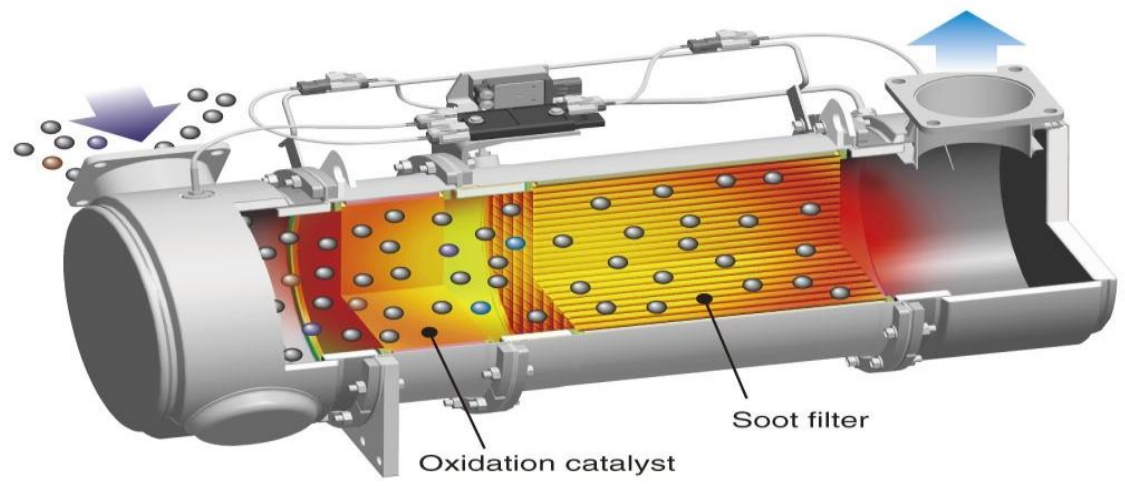

Figure-1.Disel Paticulate Filter

It was recognized that the automobile was one of the major contributors to the problem, and by the 1960s emission standards were beginning to be enforced in California. During the next decades, emission standards were adopted in the rest of the United States and in Europe and Japan. By making engines more fuel efficient, and with the use of exhaust after treatment, emissions per vehicle of $\mathrm{HC}, \mathrm{CO}$, and NOx were reduced by about $95 \%$ during the 1970 s and 1980s. Lead, one of the major air pollutants, was phased out as a fuel additive during the 1980s. However, during this time the number of automobiles greatly increased, resulting in no overall decrease in fuel usage. Additional reduction will be difficult and costly. As world population grows, emission standards become more stringent out of necessity. The strictest laws are generally initiated in California, with the rest of the United States and world following. Although air pollution is a global problem, some regions of the world still have no emission standards or laws [4].Diesel particulate filters (DPF) also called as 'particulate traps' have been developed to filter out PM from the diesel exhaust gases to meet very stringent emission limits. Alumina coated wire mesh, ceramic fiber, porous ceramic monoliths etc., have been studied as filtration media. Presently, ceramic monolith of honeycomb type structure is used to trap the particulate matter as the gas flows through its porous walls [5]. These filters are also termed as 'ceramic wall flow filters'
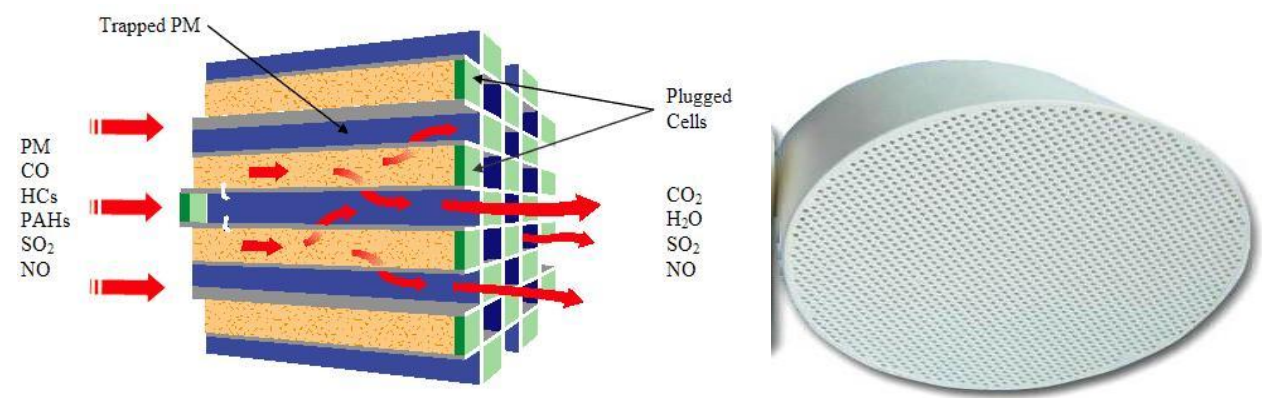

Figure-2. Disel Paticulate Filter Sectional View

A ceramic honeycomb type particulate filter is shown in Fig1. In this cellular structure, alternate cells are plugged at one end and open at the opposite end. The exhaust gas enters the cells that are open at the upstream end and flows through the porous walls to the adjacent cells. The adjacent cells are open at the downstream end from where the filtered gas exits .to the atmosphere. Flow path of gas through walls of the filter is also shown on Fig 2. [5].

\subsection{Material and Structure of DPF}

Porous cordierite ceramic has been commonly used for diesel particulate filters. It is chemically inert, has low coefficient of thermal expansion and has melting temperature of $1460^{\circ} \mathrm{C}$.the soot burns without catalyst at a temperature of 500 to $600^{\circ} \mathrm{C}$ on typical substrate surface. However, if the soot starts to burn uncontrollably the DPF may experience very high temperatures resulting in melting of the ceramic cordierite [6]. Maximum temperature attained during uncontrolled regeneration depending upon the soot loading for the two structures of cordierite DPF are shown in graph1.The maximum temperature of about $1300^{\circ} \mathrm{C}$ is reached in the DPF having $100-$ CPSI substrate when soot loading was $12 \mathrm{~g} /$ liter of substrate volume. The substrate of 200-CPSI and 0.019 in wall thickness attended temperature lower than 1000C for the same soot loading as it had higher thermal 
capacity due to larger number cells and greater wall thickness. More advanced materials capable due to larger number of cells and greater wall thickness. More advanced materials capable of withstanding even higher temperature have been developed. Materials of (NZP) family like $\mathrm{NaZr}_{2} \mathrm{P}_{3} \mathrm{O}_{12}$, and silicon carbide (Sic) have been developed for application to diesel particulate filters. Melting point of NZP materials is $1900^{\circ} \mathrm{C}$ and Sic of about $2400^{\circ}$ C.For applications where high temperature stability and strength are critical, silicon carbide is being used as material of filtration substrate. Figure 1 maximum temperature attended during uncontrolled regeneration for two diesel particulate filters (144mm diameter \& 150mm length )having 100/17 and 200/19 cordierite substrates.
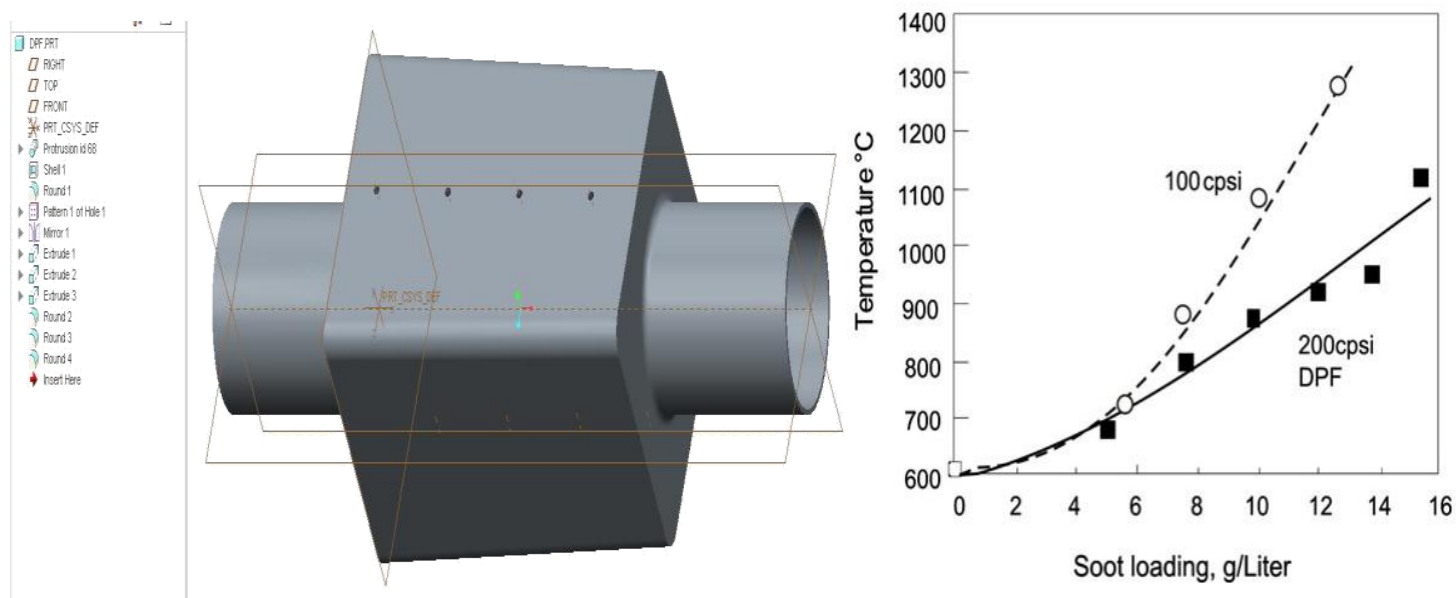

Figure-3. Disel Paticulate Filter Temperature Variation With Soot

DPF commonly have a cell density of 100-CPSI (cells $\left./ \mathrm{in}^{2}\right)$ with $0.017 \mathrm{in} .(0.43 \mathrm{~mm})$ wall thickness, designed as 100/17 cell structure substrate. The 200-CPSI structure with 0.012 in. $(0.30 \mathrm{~mm})$ wall thickness also have been used. For good mechanical strength, wall porosity is kept about 48-50\%. Pore size range from 12 to $35 \mu \mathrm{m}$. Pore size of about $35 \mu \mathrm{m}$ gives filtration efficiency of $60-75 \%, 20$ to $25 \mu \mathrm{m}$ pore size filters are used for $80-90 \%$ efficiency and 12 to $14 \mu \mathrm{m}$ pore size for efficiency $>90 \%$. With higher pore size filtration efficiency as well as pressure drop is low. Hence, optimization of pore Size, cell density and wall thickness is essential. Soot loading before regeneration ranges 5 to $10 \mathrm{~g} / 1$ volume of substrate. When a 10-20 $\mu \mathrm{m}$ pore size DPF was loaded with soot in the range of 5 to $10 \mathrm{~g} /$ liter of substrate volume, pressure drop was $7 \mathrm{KPa}$ and $11 \mathrm{KPa}$ with 5 and 10 g/liter soot loading, respectively [7].

\subsection{Regeneration}

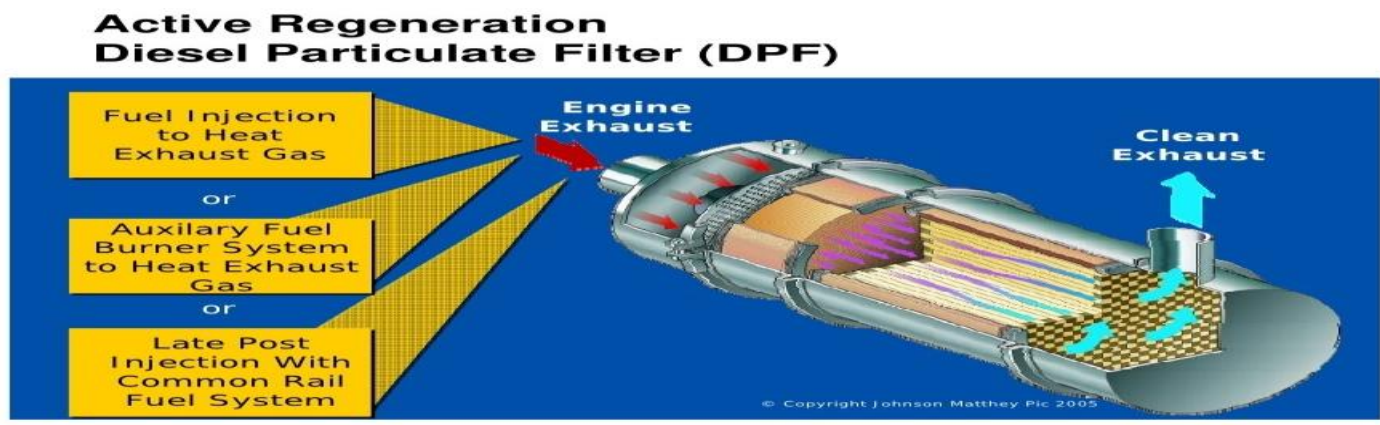

Figure-4. Regeneration

The DPF is actually a ceramic filter that has thousands of tiny channels. DPF collects soot (particulate matter) created by engine as the exhaust passes through these channels, soot is trapped along the channel walls and is prevented from exhausting through the stacks, which also protects the environment. Solid matter is trapped periodically; the DPF must remove the soot that has built up along the channel walls. This is called "regeneration". It likes a self-cleaning oven regeneration is an oxidation process that uses heat to remove the soot from the filter [8]. 


\subsection{Types of Regeneration}

1. Active regeneration

2. Passive regeneration

1. Active Regeneration

In this system sensors monitor the particulate build up by measuring pressure drop across the trap .on receiving the signal from the sensor, the exhaust gas temperature is increased above $500{ }^{0} \mathrm{C}$ by one of the following techniques:

1. Engine throttling

2. Use of burner up-stream of filter

3. Use of electric heater up-stream of filter.

\subsection{Engine Throttling}

Throttling air to the engine increases exhaust gas temperatures. Reduction in air flows would result in decrease of overall air fuel ratio, which increases the combustion temperatures resulting in higher exhaust temperatures. Throttling on the other hand decreases oxygen concentration of exhausting. At high engine loads with sufficient oxygen ability throttling can effect regeneration. Engine throttling however, has several *disadvantages. They are:

1. It increases HC and Carbon Mono oxide

2. Smoke emissions and results in higher fuel consumptions as the engine operates at significantly lower overall air flow ratio.

\subsection{Use of Burner up Stream of Filter}

A diesel fuel burner placed in the exhaust, in front of the filter, has been employed to regenerate the diesel particulate filter. This system can accomplish regeneration at all engine speeds and loads.

\subsection{Use of Electrical Heater Upstream of Filter}

Electric filter regeneration is similar in principle to the burner by pass system except that and electric resistance replaces the complex burner and electronic controls. Power to the electric heater is supplier by the engine alternator. Air pump is switched on only after the filter inlet phase has been heated to the soot burning temperature. A typical truck DPF of regeneration system may require a $3 \mathrm{KW}$ heater. Periodically the control system activates the diesel fuel burners or electric heaters to start the regeneration cycle. Regeneration may be required typically every two hours and regeneration cycle lasts for 8-10 minutes. When the back pressure value approaches the value for clean filter, it indicates the completion of the regeneration cycle. This type of Active regeneration system is complex and expensive.

\subsection{Passive Regeneration (Catalytic Regeneration)}

The passive regeneration system employs catalysts to reduce soot oxidation temperatures to the levels that lie within the normal exhaust gas temperature range. The catalyst either can be added to the diesel fuel in the form of additives or it can be coated on the surface of the filter substrate. Another approach for passive regeneration is to install a specially designed oxidation catalyst in front of the ceramic wall flow particulate filter to promote soot oxidation. This system is known as continuously regenerating trap (CRT) [9].

With passive regeneration, the carbon soot particles are burnt off continually without intervention from the engine management system. The particulate filter is positioned in close proximity to the engine. This assures that exhaust gas temperatures of $350-500{ }^{\circ} \mathrm{C}$ are reached on motorways, for example. The carbon soot particles are thereby converted into carbon dioxide by a reaction with nitrogen oxide. This gradual process occurs slowly and continually through the platinum coating, which works as a catalyst [10].

From the nitrogen oxides present in the exhaust gas (NOX) and oxygen $(\mathrm{O} 2)$, nitrogen dioxide (NO2) is produced via the platinum coating.

\section{$\mathrm{NOX}+\mathrm{O2}$ reacts to $\mathrm{NO2}$}

The nitrogen dioxide (NO2) reacts with the carbon (C) of the carbon soot particles. As a result, carbon monoxide $(\mathrm{CO})$ and nitrogen monoxide $(\mathrm{NO})$ are formed.

\section{$\mathrm{NO} 2+\mathrm{C}$ reacts to $\mathrm{CO}+\mathrm{NO}$}

The carbon monoxide $(\mathrm{CO})$ and nitrogen monoxide $(\mathrm{NO})$ combine with oxygen $(\mathrm{O} 2)$ and form nitrogen dioxide (NO2) and carbon dioxide (CO2).

\section{$\mathrm{CO}+\mathrm{NO}+\mathrm{O} 2$ reacts to $\mathrm{NO} 2+\mathrm{CO} 2$}

The cerium fuel additives get converted to cerium oxide on combustion in the engine and the cerium oxide on reaching the DPF catalysis the soot oxidation. Its mechanism of action is as below Oxidation off soot: $2 \mathrm{CeO} 2+\mathrm{C}$ reacts to $\mathrm{Ce} 2 \mathrm{O} 3+\mathrm{CO}$ 


\subsection{Experimental Procedure}

\section{Experimentation And Result}

At first give the power supply to the signal panel and then switch on the motor. Then Start the engine at zero load, wait for steady. After steady state has been reached note down the performance of the engine at various load and then measure the smoke density with the help of smoke meter and the percentage of emissions in the exhaust gas by using multi gas analyzer. Now install the DPF to the exhaust pipe and then note down the performance of the engine and measure the smoke density and percentage of emissions in the exhaust gas. Now compare the values with and without DPF.

\subsection{Engine Performance}

The engine performance is calculated in terms of indicated power, brake power, specific fuel consumption, engine speed, etc. The performance of the engine was found out without DPF and then calculated by installing the DPF in to the exhaust pipe.

\section{Smoke Measurement}

The density of the smoke in the exhaust gas is expressed in terms of smoke density or hartiz smoke unit (HSU). Here the density of the smoke first measure from the exhaust gas without DPF and then the smoke density is measured after the installation of DPF into the exhaust pipe by using smoke meter. The smoke measurement data is figured column as shown below

\section{Emission Measurement and Results}

The emission measurement test is done to calculate the percentage of volume of CO, CO2 and NOX (in ppm).The measurement is done by using a Multiple gas analyzer. The following listed figures shows the emissions with and without DPF

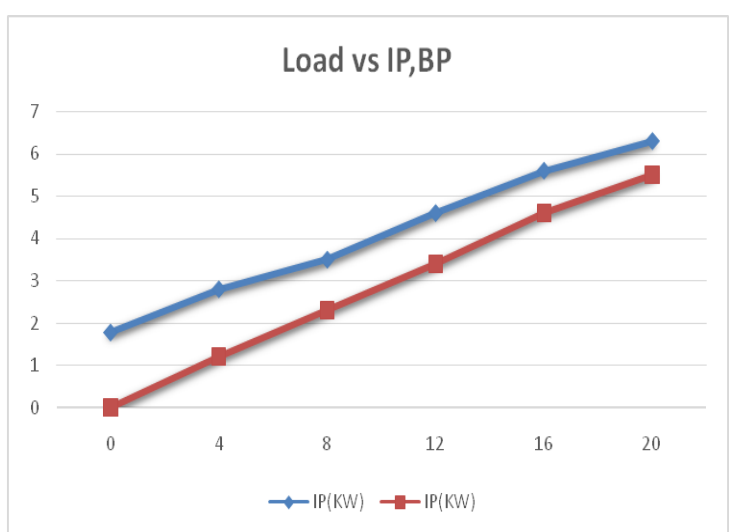

Figure-5. Load vs. IP, BP

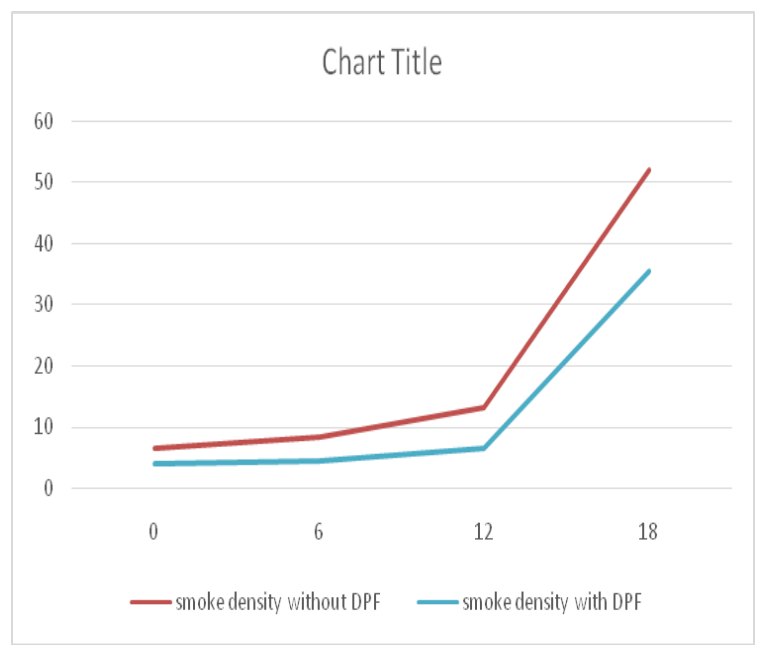

Figure-7. Density chart

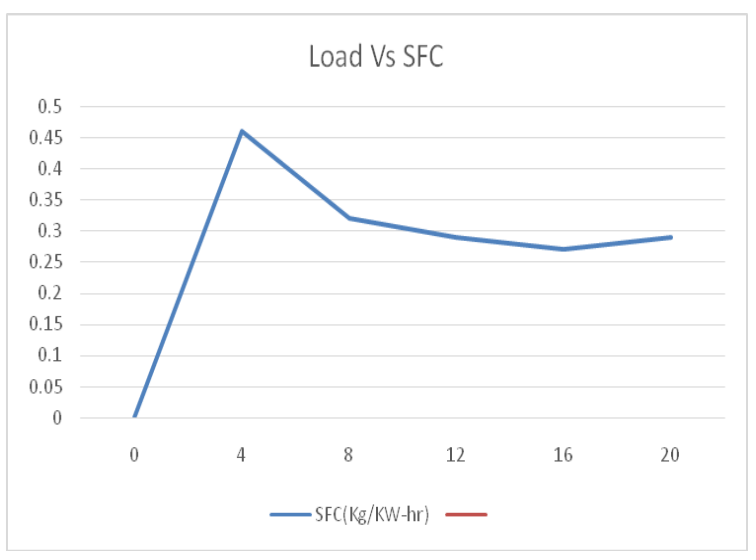

Figure-6. Load vs. SFC

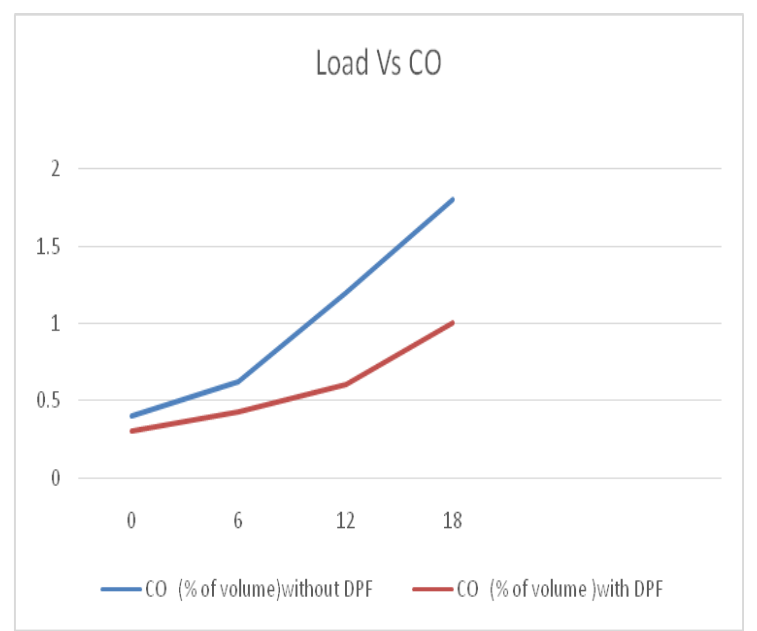

Figure-8. Load vs CO 


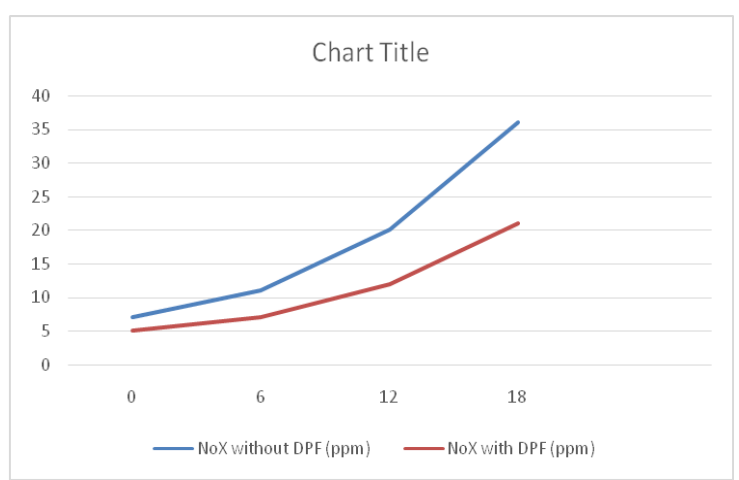

Figure-9. Density with and with out

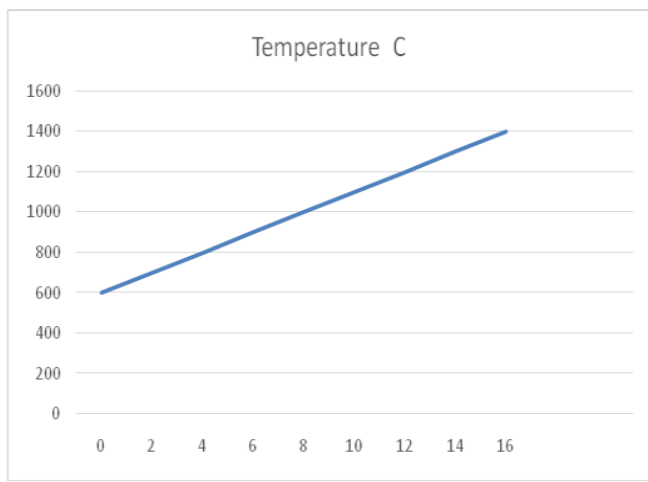

Figure-10. Load vs. Temp

\section{Conclusion}

- The smoke density (HSU) is found to be reduced by 52 HSU to 35 HSU at $18 \mathrm{~kg}$ load when DPF is installed.

- $\quad$ The emissions (CO, CO2, and NOX) are found to be considerably reduced.

- These are useful information to develop future on-board DPF system for the after-treatment of diesel exhaust.

\section{Future Scope}

A standard DPF system can be fabricated by observing and modifying the existing DPF models. The additional feature of that can be added is a regenerated system to recharge the DPF without mechanically removing or cleaning the filters. The passive regenerative DPF models have much used in future especially for the heavy engine used for power generation.

[1]. Engine Emissions by B.P.Pundir.

\section{References}

[2]. Y. Uchida, S. Ichikawa, T. Harada. Durability Study on Si-Sic Material for DPF[C]. SAE Paper 2003-01-0384.

[3]. M. Harada, S. Ichikawa, A. Otsuka, et al. Durability Study on Si-SiC Material for DPF (3)[C]. SAE Paper 2005-01$0582,2005$.

[4]. 4.Cheng Li, Frank Mao, Reggie Zhan, et al. Durability Performance of Advanced Ceramic Material DPFs[C].SAE Paper 2007-01-0918, 2007.

[5]. SaurabhMathur, John H. Johnson, Jeffrey D. Naber, et al. Experimental Studies of an Advanced Ceramic Diesel Particulate Filter[C]. SAE Paper 2008-01-0622, 2008.

[6]. Motor vehicle emissions regulations and fuel specification historic review 1996-2000.

[7]. Mackinven and Hublin"European Program on emissions, Fuels and Engine technology- objective and design",SAE paper 1996.

[8]. B. J. Cooper and J. E. Thoss, "Role of NO in diesel particulate emission control," SAE, Warrendale, PA, SAE Paper 89040, 1989.

[9]. Dianna M. Young, David L. Hickman, GarimaBhatia,etal. Ash Storage Concept for Diesel Particulate Filters[C]. SAE Paper 2004-01-0948, 2004

[10]. R. Matarresea, L. Castoldia, L. Lietti, and P. Forzatti, "Soot combustion: Reactivity of alkaline and alkaline earth metal oxides in full contact with soot," Catal. Today, vol. 136, no. 1, pp. 11-17, Jul. 2008.

[11]. K. Nakatani, S. Hirota, S. Takeshima, K. Itoh, T. Tanaka, and K. Domae, "Simultaneous PM and NOx reduction system for diesel engines," presented at the 2002 SAE World Congr. Exhib., Detroit, MI, Mar. 2002.

[12]. United States Environmental Protection Agency, Technical Highlights, EPA420-F03-022, 2003, p. 1.

[13]. G. A. Stratakis, D. L. Psarianos and A. M. Stamatelos, "Experimental investigation of pressure drop in porous ceramic filters." Proc. Instn MechEngrs, Volume 216, Part D: J Automobile Engineering.

[14]. Konstandopoulos, A.G., Papaioannou, E., "Update on the science and technology of diesel particulate filters. KonaPowder, 2008, Part. 26: 36-65.

[15]. Athanasios G. Konstandopoulos, M. K., SouzanaLorentzou, Chrysa Pagkoura and EleniPapaioannou. 2007, "Soot Oxidation Kinetics in Diesel Particulate Filters."SAE-2007-01-1129.

[16]. Konstandopoulos, A. G. 2003. "Flow Resistance Descriptors for Diesel Particulate Filters: Definitions, Measurements and Testing." SAE-2003-01-0846.

[17]. Bilal Zuberi, James J. Liu, Sunilkumar C. Pillai, et al. Advanced High Porosity Ceramic Honeycomb Wall Flow Filters[C]. SAE Paper 2008-01-0623, 2008. 